\title{
PKM PENGEMBANGAN DAN MANAJEMEN BUMDES DI DESA TIWOHO KECAMATAN WORI KABUPATEN MINAHASA UTARA
}

\author{
Cynthia Maria Siwi, Jetty Erna Hilda Mokat \\ Universitas Negeri Manado \\ mariasiwi@ecampus.ut.ac.id, jettymokat@unima.ac.id
}

\begin{abstract}
Abstrak
Tujuan dari pengabdian ini adalah; (1) Memenej dan menata kelembagaan Adminitrasi Desa Tiwoho khususnya pada tata kelola struktur administrasi BUMDes di Desa Tiwoho Kecamatan Wori Kabupaten Minahasa Utara; (2) Melalui Penguatan Sumber daya; Pelaku usaha dapat kreatif, inovativ dan termotivasi Menumbuhkan sikap kemandirian dan kualitas hidup masyarakat desa tiwoho; (3) Adanya pendampingan dan keberlanjutan pengembangan jenis usaha melalui pemanfaatan dana BUMDes.

Lokasi pengabdian bertempat di Desa Tiwoho Kecamatan Wori Kabupaten Minahasa, menggunakan metode Focus Group Disscussion (FGD), ceramah, partisipatif, dan latihan. Hasil yang didapatkan adalah Pada dasarnya semua program yang dikerjakan tidak lepas dari apa yang menjadi kebutuhan di Desa Tiwoho, Kecamatan Wori, Kabupaten Minahasa Utara. Hal tersebut juga menjadi latar belakang dari perencanaan serangkaian pengadaan program baik kelompok yang menjadi program unggulan. Secara keseluruhan, berbagai program PKM dapat dilaksanakan dan berjalan sesuai dengan sasaran yang telah direncanakan.
\end{abstract}

\section{Kata kunci: Administrasi, Tiwoho, BUMDes}

\section{PENDAHULUAN}

\section{Analisis Situasi}

Desa merupakan unit terkecil dari negara yang terdekat dengan masyarakat dan secara riil langsung menyentuh kebutuhan masyarakat untuk disejahterakan. Basis sistem kemasyarakatan di desa yang kokoh adalah kekuatan untuk mengembangkan sistem politik, sosial, budaya, dan ekonomi. Di Indonesia ada sejumlah 74.093 desa, dimana lebih dari 32 ribu desa masuk dalam kategori desa tertinggal. Kondisi ini sangat kontradiktif dengan tujuan otonomi daerah.

Jika hampir separuh desa di Indonesia masih tergolong desa tertinggal, maka tidak heran jika hingga kini desa masih identik dengan kemiskinan dan keterbelakangan. Terbitnya UU Nomor 6 Tahun 2014 tentang
Desa memimpikan kehidupan desa yang otonom dalam mengelola pemerintah dan kemasyarakatannya. Pada PP Nomor 43 Tahun 2014 yang diubah melalui PP Nomor 47 Tahun 2015 telah menyebutkan jika kini desa mempunyai wewenang untuk mengatur sumber daya dan arah pembangunan. Untuk itu tumpuan dinamika kehidupan desa sangat bergantung pada pastisipasi masyarakat dalam mendorong terbangunnya kesepakatan pengelolaan desa, mampu menumbuhkan dan mengembangkan nilai sosial, budaya, ekonomi, dan pengetahuan. Berlakunya regulasi tentang desa membuka harapan bagi masyarakat desa untuk berubah. Hal tersebut menjadi momentum untuk mendorong lahirnya desa dengan tata kelola yang lebih akuntabel dan transparan, masyarakat desa 
yang partisipatif, dan perekonomian desa yang menghidupi [3].

Penyelenggaraan pemerintahan desa, diatur dalam Undang-Undang No 6 Tahun 2014 tentang Desa. Pelaksanaan kegiatan Penelitian ini didasarkan pada fenomena yang terjadi yaitu kurangnya program kegiatan pemberdayaan masyarakat dan tingkat ekonomi masyarakat Desa Tiwoho yang masih rendah karena masyarakat Desa Tiwoho ratarata bekerja sebagai petani, buruh tani, buruh dan pedagang kecil serta pengangguran yang masih usia produktif, diharapkan keberadaan BUM Desa mampu mendorong dinamisasi kehidupan ekonomi serta sebagai penggerak perekonomian masyarakat desa dan diharapkan dapat meningkatkan kesejahteraan masyarakat desa, serta dapat membentuk lembaga struktur BUMDes di Desa Tiwoho, hal ini senada dengan PMDes No.4 Tahun 2015 bahwa: Keberadaan BUMDes untuk pembangunan daerah tertinggal dan transmigrasi, tentang Pendirian, pengurusan \& pengelolaan, dan pembubaran BUMDes [7].

\section{Efektifnya pelaksanaan BUMDes} diharapkan untuk dapat memajukan desa dan menjadikan masyarakat desa yang sejahtera, melalui keaktifan lembaga desa dan terlaksananya tujuan serta program desa. Hal ini sesuai dengan pendapat Djafri. (2016:16) yang menyatakan bahwa "Efektivitas adalah usaha kepemimpinan melalui sistem managerial yang dicapai secara terukur untuk mencapai tujuan organisasi dalam arti tercapainya tujuan yang telah ditentukan sebelumnya melalui fungsi manajemen".Dalam pengelolaan badan usaha milik desa berbasis kerakyatan masyarakat desa upaya mewujudkan pencapaian tujuan dalam organisasi maka masyarakat desa juga diperlukan sumber daya manusia masyarakat desa yang berkualitas mengerti dan paham aturan- aturan dan manajemen pengelolaan administrasi dan dananya [6].

Lokasi PKM bertempat di salah satu desa Tiwoho yang berada di kecamatan Wori, Kabupaten Minahasa utara, Sulawesi utara. jumlah penduduk sebanyak 1. 116 jiwa dengan mata pencarian sebagian besar adalah petani (38\%) dan nelayan (16\%). Posisi desa mempunyai ketinggian 0-100 meter dari permukaan laut dan memiliki kondisi permukaan tanah berpasir yang datar dan berbukit. Pemukiman dan garis pantai dibatasi oleh tanggul sepanjang $200 \mathrm{~m}$ dan bakau. Luas wilayah desa adalah 556.485 Ha dengan hutan bakau 65,5 Ha (11,2\%).

Desa tiwoho juga merupakan salah satu desa yang menjadi zona IV lokasi wisata. Dimana pemerintah Minahasa utara dan Pemerintah Sulawesi utara terus melakukan pemantauan untuk perkembangan wisata di desa tiwoho. Dalam pemantauan yang dilakukan di daerah ekowisata, yang meliliki 
berbagai macam infrasturktur dalam menunjang pengembangan di desa tersebut. Infrastruktur dalam pengembangan ekowisata yaitu dibangunnya Gazebo dipinggir pantai dan dermaga. Lewat hasil kekayaan alam yang dimiliki oleh mayarakat desa tiwoho dalam hal ini masyarakat terbiasa memanfaatkan hutan bakau sebagai sumber penghidupan, diantaranya: tempat mencari kayu bakar, bahan baku pembuatan atap rumah, sumber obat-obatan tradisional, dan tempat mencari ikan. Desa Tiwoho juga dikenal dengan daerah Sumber daya alam yang baik, dimana masyarakat memiliki banyak sekali penhasilan di daerah tersebut. Mulai dari ikan laut, dan berbagai jenis Sumber Daya Alam yang ada di desa tersebut.

Dalam pengembangan ekowisata peran kelompok masyarakat seperti kelompok tani, kelompok nelayan, dan kelompok agama yang ada melibatkan diri dalam usaha pelestarian ekosistem hutan bakau. kelompok ini juga rutin dalam menjaga dan melestarikan hutan bakau yang ada dipantai. Jika dilihat dari analisis situasi, desa Tiwoho merupakan salah satu desa yang memilki berbagai kekayaan alam, mulai dari ikan laut, bahkan hutan bakau dan berbagai jenis Sumber Daya Alam lainnya.

1. Bidang Pendidikan Mayarakat Desa Tiwoho mayoritas sudah sadar pendidikan, di mana masyarakat sudah sadar pentingnya pendidikan baik untuk anak usia dini maupun di tingkat yang lebih tinggi. Selain terdapat sekolah juga terdapat kegiatan Ekstrakulikuler dan Pusat Pengembangan Anak (PPA). Kegiatan tersebut dilakukan di Sekolah dan Gereja yang diikuti oleh anak-anak SDRemaja. Kegiatan ini juga dikelola dengan baik dan bekerja sama dengan pemerintah desa dan masyarakat desa.

2. Bidang Pertanian

Desa Tiwoho memiliki potensi yang cukup tinggi dibidang pertanian. Dalam hal ini banyak sekali masyarakat di desa Tiwoho yang memanfaatkan pendapatan lewat hasil pertanian seperti kelapa, pala, cengkih, dan cabai.

3. Bidang Peternakan

Desa tiwoho mempunyai potensi dibidang peternakan. Masyarakat desa yang memiliki hewan ternak seperti kambing, sapi, dan ayam. Masyarakat tidak hanya memelihara hewan tersebut untuk dikonsumsi sendiri, namun juga untuk diternak. Namun yang menjadi kendala belum adanya tempat untuk berternak sehingga perternakan warga kebanyakan berada disekitar rumah warga sendiri.

4. Bidang Beragama

Kehidupan beragama dalam 
masyarakat desa tiwoho memiliki berbagai aliran agama yang terdiri dari Kristen Protestan, Kristen Katolik, Dan Islam. Walaupun memiliki banyak keragaman dan perbedaan pada aliran beragama, kehidupan beragama di desa tiwoho sangat begitu baik dan pemerintah desa juga sudah menyiapkan fasilitas dalam hal ini yaitu tempat ibadah bagi tiap umat beragama.

\section{Permasalahan Mitra}

1. Perlu Penataan administrasi kelembagaan BUMDes

2. Tingkat pengetahuan dan wawasan masyarakat desa yang rendah terkait pentingnya membentuk kelompok usaha

3. Kurangnya pengetahuan pengurus dalam manajemen BUMDes sehingga kinerja kelembagaan BUMDes dalam pengembangan usaha kurang optimal

4. Kurangnya pembinan bagi Orang yang berjiwa pengusaha/pelaku usaha (entrepreneur); kepribadian yang kuat, mental wirausaha, kepekaan lingkungan

5. Kurangnya keahlian yang dimiliki oleh lembaga pendidikan dan masyarakat

6. Kurangnya pemahaman IT sebagai media promosi yang dapt memasarkan hasil usahanya, sebab pelaku usaha putus sekolah/tidak melanjutkan pendidikan dan terpaksa bekerja karena awalnya desakan untuk menghidupi keluarga.

\section{TARGET DAN LUARAN}

\section{Rencana Luaran}

Luaran yang ingin dicapai oleh kegiatan Pelatihan Manajemen Badan Usaha Milik Desa adalah sbb:

1. Memenej dan menata kelembagaan Adminitrasi Desa Tiwoho khususnya pada tata kelola struktur administrasi BUMDes di Desa Tiwoho Kecamatan Wori Kabupaten Minahasa Utara, sehingga dengan hal ini dapat membekali Aparat desa dalam hal ini pengurus BUMDes memahami tugas pokok dan tanggungjawabnya dalam mengelola Dana BUMDes, melalui kejelasan struktur organisasi, melalui manajemen administrasi, infrastruktur dan pelaporan keuangan

2. Melalui Penguatan Sumber daya; Pelaku usaha dapat kreatif, inovativ dan termotivasi Menumbuhkan sikap kemandirian dan kualitas hidup masyarakat desa tiwoho. sehingga pendapatan masyarakat yang tinggal di Desa Tiwoho Kecamatan Wori Kabupaten Minahasa Utara dapat lebih bertambah bidang usaha yang di tekuni sehingga kesejahteraan masyarakatnya meningkat. 
3. Dapat menjalin kerjasama dengan pihak lain yang berkompoten; pemerintah maupun swasta untuk mempertahankan dan lebih aktif dalam menambah modal, agar usaha lebih baik dan terus meningkat serta di kenal oleh masyarakat luas melalui promosi usaha, melalui; pameran danlainnya.

4. Adanya pendampingan dan keberlanjutan pengembangan jenis usaha melalui pemanfaatan dana BUMDes, sehingga dana desa dapat terdistribusi dengan merata dan berdampak baik serta hasil yang maksimal, melalui macam produk usaha yang bernilai ekonomis, sosial dan dapat melestarikan serta memanfaatkan hasil lingkungan atau sumberdaya alam.

\section{Target Luaran}

1. Lebih kepada edukasi dan memenej agar lebih inovasi dalam mengeksplorasi sumberdaya alam dan bersumber daya manusia melalui pemanfaatan dana BUMDes untuk meningkatkan penguasaan dalam bidang pelatihan Manajemen Usaha milik Desa untuk penguatan pemberdayaan Desa melalui bidang ekonomi, sosial dan lingkungan sekitar. Untuk usaha yang sudah produksi hasil usaha, lebih meningkatkan berbagai macam produksi hasil usahanya dan yang belum produksi hasil usaha dapat lebih di optimalkan, sehingga dapat meningkatkan menjadi berbagai produk-produk hasil usaha, yang bernilai ekonomis. Untuk penguatan usaha di desa, pelaku usaha di bekali dengan pelatihan dan Bimtek agar pelaku usaha lebih termotivasi dan peka akan kebutuhan dan keadaan masyarakat yang kurang mampu dalam hal ekonomi, sehingga masyarakat lebih mandiri dan sejahtera.

2. Sebagai suatu bentuk kepedulian dari Universitas Negeri Manado dalam meningkatkan kemandirian dan taraf hidup masyarakat khususnya Di Desa Tiwoho. dengan menanggulangi masalah perekonomian Di Desa Tiwoho, penambahan angka pengangguran dan Kemiskinan. 3 . Membantu Program Pemerintah dan masyarakat Desa Tiwoho yang kurang mampu untuk meningkatan kesejahteraan melalui Pelatihan Manajemen BUMDes dalam penguatan kelembagaan dan peningkatan produksi usaha di Desa Tiwoho Kecamatan Wori Kabupaten Minahasa Utara 
3. Sebagai suatu bagian dari tridarma perguruan tinggi Universitas Negeri Manado dalam membangun dan meningkatkan taraf hidup kesejahteraan masyarakat Desa Tiwoho.

\section{Solusi yang ditawarkan}

1. Perlunya sosialisasi terhadap masyarakat agar mereka mengetahui pentingnya partisipasi dalam program BUMDes untuk meningkatkan pendapatan dan perekonomian desa.

2. Membentuk dan melantik Pengurus BUMDes di Desa Tiwoho Kecamatan Wori Kabupaten Minahasa Utara. Agar sistem kelembagaan BUMDes Di Desa Tiwoho lebih termenej dan tertata dengan baik.

3. Perlunya pelatihan keterampilan tentang manajemen BUMDes kepada pengurus agar meningkatkan kinerja kelembagaan BUMDes sehingga usahanya meningkat

4. Mengajukan bantuan modal kepada pihak ketiga, tidak hanya mengandalkan bantuan dari Pemerintah Kabupaten saja, termasuk dari BUMDes.

5. Bimtek: (1) Sistem Informasi untuk mempublikasikan/ keberadaan BUMDes. (2) Promosi/Pemasaran (IT) hasil Usaha Desa

\section{METODE PELAKSANAAN \\ Metode/Konsep Yang Digunakan}

Metode yang digunakan yaitu metode Focus Group Disscussion (FGD), ceramah, dan partisipatif, dan latihan. Teknik pelaksanaan kegiatan yang digunakan berupa observasi, wawancara serta dokumentasi. Sedangkan untuk pelaporan kegiatanya adalah: melalui analisis data lapangan, dokumentasi dan penarikan kesimpulan yang disajikan dalam laporan kegiatan. Kegiatan Penelitian ini menggunakan pendekatan strategi sinergitas sesuai potensi dan masalah pemecahannya yang menyeluruh meliputi tujuan, sasaran, lingkup, koordinasi, komunikasi aktif, target dan luaran.

Bentuk pelaksanaan kegiatan Penelitian dilaksanakan secara pendampingan antara Perguruan Tinggi; Anggota Tim Penelitian, Mahasiswa Universitas Negeri Manado, Aparat Desa dan Masyarakat Desa Tiwoho, dengan formulasi bentuk kegiatannya;

(1) Pembentukan Administrasi kelembagaan BUMDes, melalui pelantikan pengurus BUMDes oleh pejabat yang berwenang

(2) FGD untuk pelatihan manajemen Profesi admistrasi, melalui Narasumber Ahli keilmuan bidang Manajemen \& Administrasi, dalam bentuk ceramah, diskusi dan dialog fokus. Adapun bentuk konsep materi pelatihan; pelatihan dalam 
bentuk Focus Group Discussion (FGD) untuk usaha yang sudah terbentuk dari awal BUMDes dapat di tingkatkan melalui;

(2.1) pelatihan peningkatan manajemen usaha desa, sebagai penguatan untuk pemberdayaan masyarakat dalam meningkatkan perekonomian usahanya, dengan tujuan memenej orang-orang yang berjiwa pengusaha (entrepreneur), (2.2) Menjelaskan kepada masyarakat tentang keberadaan BUMDes, agar dapat membantu jenis usaha yang dapat di danai.

(2.3) Melatih ketrampilan masyarakat untuk peningkatan potensi usaha masyarakat di desa Tiwoho.

(3) Pelatihan usaha desa ini melalui kelompok partisipatif pendampingan terintegrasi, yang di petakan dalam 3 (tiga) kelompok kerja mahasiswa; yakni kelompok pertama; untuk Penataan Desa Tiwoho; kelembagaan, Perencanaan program dan implementasi program dan kelompok BUMDesa, serta Pengelolaan Anggaran yaitu: laporan akuntabilitas dan Transparansi pelaporan penggunaan anggaran. Kelompok, dua; FGD Pelatihan Manajemen Usaha Milik Desa, ketiga; Pelatihan Pemasaran dan Promosi Usaha, Melalui Informasi Teknologi. Capaian akhir kegiatan Penelitian ini adalah: Melalui Pelatihan Manajemen Usaha Milik
Desa diharapkan dapat memberi Penguatan Pemberdayaan Desa Tiwoho melalui BUMDes dalam peningkatan Peran Kepala Desa untuk mencapai Tujuan, sasaran, program desa yang efektif, mandiri dan sejahtera

Persiapan dan Desain Rancangan FGD

1. Membentuk Tim

Tim FGD umumnya mencakup:

- Moderator, yaitu fasilitator diskusi yang terlatih dan memahami masalah yang dibahas serta tujuan penelitian yang hendak dicapai (ketrampilan substantif),

- Asisten Moderator/co-fasilitator, yaitu orang yang intensif mengamati jalannya FGD.

- Pencatat Proses/Notulen, yaitu orang bertugas mencatat inti permasalahan yang didiskusikan serta dinamika kelompoknya.

- Penyedia Logistik, yaitu orang-orang yang membantu kelancaran FGD berkaitan dengan penyediaan transportasi, kebutuhan rehat, konsumsi, akomodasi (jika diperlukan), insentif (bisa uang atau barang/cinderamata), alat dokumentasi, dll.

- Dokumentasi, yaitu orang yang mendokumentasikan kegiatan dan dokumen FGD: memotret, merekam (audio/video), dan menjamin berjalannya alat-alat dokumentasi, 
terutama perekam selama dan sesudah FGD berlangsung.

- Lain-lain jika diperlukan (tentatif),

\section{Memilih dan mengatur tempat}

Pada prinsipnya, FGD dapat dilakukan di mana saja, namun sebaiknya tempat FGD yang dipilih hendaknya merupakan tempat yang netral, nyaman, aman, tidak bising, berventilasi cukup, dan bebas dari gangguan yang diperkirakan bisa muncul.

3. Menyiapkan Logistik

Logistik adalah berbagai keperluan teknis yang dipelukan sebelum, selama, dan sesudah FGD terselenggara.

Menyusun Pertanyaan FGD

Agar pelaksanaan FGD berjalan lancar dan informasi yang di dapat sesuai dengan tujuan dari penelitian, diperlukan penyusunan pertanyaan/Guideline FGD. Tujuannya agar diskusi dapat berjalan terstruktur tidak keluar dari tujuan yang sudah ditentukan agar hasil dari FGD tersebut dapat merepresentasikan alasan, motivasi, tujuan dll yang berhubungan dengan topik/pembahasan yang di diskusikan [8].

\section{Pelaksanaan FGD}

Seperti yang sudah di jelaskan di awal bahwa dalam pelaksanaan FGD agar diskusi yang dilakukan berjalan baik (terarah/fokus, tidak ramai karena semua peserta ingin berbicara mengeluarkan pendapat, informasi dapat terjawab sesuai dengan harapan dan tujuan
FGD) dibantu dengan seseorang yang dapat memfasilitatorkan para peserta lainnya yang dinamakan moderator.

\section{HASIL DAN PEMBAHASAN}

\section{Gambaran Iptek}

Pengertian BUMDes

Menurut Pasal 107 ayat (1) huruf (a) Undang-Undang Nomor 22 Tahun 1999 dinyatakan bahwa sumber pendapatan Desa salah satunya adalah pendapatan asli desa, yang meliputi: 1) hasil usaha desa; 2) hasil kekayaan desa; 3) hasil swadaya dan partisipasi; 4) hasil gotong royong; dan 5) lainlain pendapatan asli desa yang sah. Penjelasan Pasal 107 ayat (1) menyebutkan bahwa pemberdayaan potensi desa dalam meningkatkan pendapatan desa dilakukan, antara lain, dengan pendirian Badan Usaha Milik Desa, kerja sama dengan pihak ketiga, dan kewenangan melakukan pinjaman.

$$
\text { Selanjutnya menurut Pasal } 213 \text { ayat }
$$

(3) Undang-Undang Nomor 32 Tahun 2004 tentang Pemerintahan Daerah, yang menyatakan bahwa sebagai suatu lembaga ekonomi modal usahanya dibangun atas inisiatif masyarakat dan menganut asas mandiri. Ini berarti pemenuhan modal usaha BUMDes harus bersumber dari masyarakat. Meskipun demikian, tidak menutup kemungkinan BUMDes dapat mengajukan pinjaman modal kepada pihak luar, seperti dari Pemerintah Desa atau pihak lain, bahkan 
melalui pihak ketiga. Pengertian lain tentang BUMDes terdapat dalam Pasal 1 ayat (6) Peraturan Menteri Dalam Negeri Nomor 39 Tahun 2010 Tentang Badan Usaha Milik Desa, yang menyatakan bahwa BUMDes adalah usaha desa yang dibentuk/didirikan oleh pemerintah desa yang kepemilikan modal dan pengelolaannya dilakukan oleh pemerintah desa dan masyarakat [2].

Selanjutnya BUMDes dalam Pasal 78

Peraturan Pemerintah Nomor 72 Tahun 2005 Tentang Desa dinyatakan bahwa dalam rangka meningkatkan pendapatan masyarakat dan desa, Pemerintah Desa mendirikan Badan Usaha Milik Desa (ayat 1) Pembentukan Badan Usaha Milik Desa ditetapkan dalam Peratuan Desa dengan berpedoman pada peraturan perundangundangan (ayat 2). Bentuk Badan Usaha Milik Desa harus berbadan hukum (ayat 3) [4].

Menurut Pusat Kajian Dinamika Sistem Pembangunanm Badan Usaha Milik Desa (BUMDes) adalah lembaga usaha desa yang dikelola oleh masyarakat dan pemerintahan desa dalam upaya memperkuat perekonomian desa dan dibentuk berdasarkan kebutuhan dan potensi desa. Sebagai salah satu lembaga ekonomi yang beroperasi dipedesaan, BUMDes harus memiliki perbedaan dengan lembaga ekonomi pada umumnya. Ini dimaksudkan agar keberadaan dan kinerja BUMDes mampu memberikan kontribusi yang signifikan terhadap peningkatan kesejahteraan warga desa. Disamping itu, supaya tidak berkembang sistem usaha kapitalistis di pedesaan yang dapat mengakibatkan terganggunya nilai-nilai kehidupan bermasyarakat [5].

Undang-Undang No. 6 Tahun 2014 tentang Desa merupakan payung hukum atas BUMDes sebagai pelaku ekonomi yang mengelola potensi desa secara kolektif untuk meningkatkan kesejahteraan masyarakat desa. Dalam UU No. 6 Tahun 2014 pasal 87 ayat 3, BUMDes dapat menjalankan usaha di bidang ekonomi dan/atau pelayanan umum sesuai dengan ketentuan peraturan perundang-undangan.

- Tujuan pendirian BUMDes, yaitu :

1. Meningkatkan perekonomian desa

2. Mengoptimalkan asset desa agar bermanfaat untuk kesejahteraan desa

3. Meningkatkan usaha masyarakat dalam pengelolaan potensi ekonomi desa

4. Mengembangkan rencana kerja sama usaha antar desa dan/atau dengan pihak ketiga

5. Menciptakan peluang dan jaringan pasar yang mendukung kebutuhan layanan umum warga

6. Membuka lapangan kerja

7. Meningkatkan kesejahteraan masyarakat melalui perbaikan pelayanan umum, pertumbuhan dan pemerataan ekonomi desa

8. Meningkatkan pendapatan masyarakat desa dan pendapatan asli desa.

- Beberapa jenis usaha yang dapat dikembangkan oleh BUMDes, yaitu : 
1. BUMDes tipe serving, yaitu menjalankan bisnis sosial yang melayani dengan melakukan pelayanan public kepada masyarakat sekaligus juga memperoleh keuntungan financial dari pelayanan itu. Contohnya usaha listrik desa.

2. BUMDes tipe banking, yaitu menjalankan bisnis seperti bank desa atau lembaga perkreditan desa.

3. BUMDes tipe renting, yaitu menjalankan bisnis penyewaan barang-barang seperti peralatan pesta, alat transportasi, ruko, dan lainlain.

4. BUMDes tipe brokering, yaitu sebagai lembaga perantara seperti jasa pelayanan kepada warga maupun usaha-usaha masyarakat, contohnya mendirikan pasar desa untuk memasarkan produk-produk yang dihasilkan masyarakat.

Penting adanya manajemen BUMDes adalah supaya BUMDes yang dijalani sukses dan dapat mencapai tujuan dari BUMDes.

- Melakukan manajemen BUMDes adalah dengan melakukan:

1. Perencanaan

Melakukan perencanaan terhadap suatu usaha dalam BUMDes sangat dibutuhkan, karena tanpa rencana maka BUMDes tidak bisa berjalan dengan baik. Di dalam perencanaan terdapat penetapan tujuan, prosedur pelaksanaan, dan program yang akan dilaksanakan.

2. Pengorganisasian

Dengan melakukan pengorganisasian maka dapat mengumpulkan orangorang dan menempatkan mereka menurut kemampuan dan keahlian dalam pekerjaan yang sudah direncanakan. Dalam pengorganisasian dilakukan pembagian tugas, wewenang, dan tanggung jawab

3. Penggerakan

Penggerakan atau tindakan yang mengusahakan agar semua anggota bekerja mencapai sasaran sesuai dengan perencanaan dan usaha-usaha organisasi. Dalam penggerakan ini dilakukan pembimbingan, diberikan arahan berupa saran, diberikan perintah untuk melakukan suatu pekerjaan.

4. Pengawasan

Dilakukan untuk mengawasi pergerakan dari organisasi BUMDes apakah sudah sesuai dengan rencana yang ditetapkan atau belum. Dalam pengawasan terdapat alat ukur untuk melakukan penilaian, dan jika terdapat kekeliruan maka dilakukan perbaikan.

- Prinsip-prinsip dalam mengelola BUMDes (Ridlwan, 2014), yaitu :

1. Kooperatif, yaitu ada partisipasi seluruh komponen dalam pengelolaan BUMDes dan mampu saling bekerja sama dengan baik.

2. Partisipatif, yaitu seluruh komponen yang terlibat dalam pengelolaan BUMDes harus memberikan dukungan serta kontribusi secara sukarela atau tanpa diminta untuk meningkatkan BUMDes.

3. Emansipatif, yaitu seluruh komponen yang ikut serta dalam pengelolaan BUMDes diperlakukan sama tanpa membedakan golongan, suku, dan agama.

4. Transparan, yaitu seluruh kegiatan yang dilaksanakan dalam pengelolaan BUMDes dan memiliki pengaruh pada kepentingan umum harus terbuka dan segala lapisan masyarakat mengetahui seluruh kegiatan tersebut. 
5. Akuntabel, yaitu seluruh kegiatan secara teknis maupun administrative harus dipertanggung jawabkan.

6. Sustainable, yaitu masyarakat mengembangkan dan melestarikan kegiatan usaha dalam BUMDesa.

- Manfaat dari keberadaan BUMDes, yaitu :

1. Manfaat ekonomi

BUMDes diharapkan mampu menggerakkan roda perekonomiann di pedesaan. BUMDes akan bergerak dengan upaya meningkatkan sumbersumber pendapatan asli desa, menggerakan kegiatan ekonomi masyarakat desa.

2. Manfaat politik

BUMDes yang berdiri secara partisipatif, dapat menjadi ruang bertemunya kelompok-kelompok minat kepentingan di desa. Kesepakatan mengenai jenis usaha maupun pembagian keuntungan.

3. Manfaat social budaya

Untuk meningkatkan pendapatan masyarakat dan pendapatan asli desa maka BUMDes berkontribusi secara social untuk memenuhi kebutuhan masyarakat akan lapangan pekerjaan.

Kendala atau hambatan yang membuat Badan Usaha Milik Desa khususnya di desa Tiwoho tidak dapat berjalan dengan baik yaitu :

1. Berdasarkan jawaban dari ketua BUMDes Tiwoho bahwa dana yang ada telah disalurkan semua dalam program BUMDes dalam hal usaha penjualan Gas LPG, hal itu dilakukan berdasarkan aturan bahwa harus menyelesaikan satu proyek setelah itu baru akan mendapatkan saluran dana lagi, tidak bisa sekaligus menjalankan dua proyek.

2. Kurangnya transparansi kepengurusan BUMDes maupun kegiatan BUMDes juga menjadi kendala sehingga BUMDes tidak dapat berjalan dengan baik.

Dari kendala-kendala di atas, maka solusi yang dapat diberikan yaitu:

1. Dalam menjalankan usaha milik desa harus benar-benar memperhatikan potensi desa yang dapat dijadikan usaha juga memperhatikan kebutuhan dari masyarakat desa yang dapat dijadikan usaha agar dana yang dikeluarkan benar-benar dimanfaatkan dengan baik, dan menghindari kerugian akibat usaha yang tidak berjalan dengan baik.

2. Harus disadari bahwa transparansi dalam kepengurusan BUMDes maupun kegiatan-kegiatan BUMDes harus dilakukan agar masyarakat mengetahui keberadaan BUMDes di desa dan masyarakat pun dapat ikut serta berpartisipasi dalam kegiatan BUMDes.

\section{Pembahasan Program}

Sosialisasi BUMDes

Program unggulan yang dilaksanakan pada kegiatan PKM ini berupa sosialisasi tentang Badan Usaha Milik Desa atau BUMDes yang sudah disosialisasikan di desa tiwoho, program sosialisasi ini bisa bejalan dengan baik. Melihat bahwa banyak kekayaan alam yang ada di desa Tiwoho yang dapat dimanfaatkan sebagai pendapatan desa sebagai badan usaha milik desa. Namun, sesuai pengamatan yang telah kami lihat di lapangan, banyak kekayaan alam yang didesa ini yang belum dimanfaatkan secara maksimal sebagai pendapatan yang mungkin bisa menjadi salah satu Badan Usaha Milik Desa di 
desa tiwoho. Dengan terlaksananya Sosialisasi Tentang BUMDes di desa tiwoho, masyarakat diharapkan mampu memanfaatkan seluruh sumberdaya alam yang ada di desa tiwoho secara efektif dan efisien, serta dapat memajukan kesejahteraan masyarakat yang ada didesa Tiwoho.

\section{KESIMPULAN}

\section{Kesimpulan}

Pada dasarnya semua program yang dikerjakan tidak lepas dari apa yang menjadi kebutuhan di Desa Tiwoho, Kecamatan Wori, Kabupaten Minahasa Utara. Hal tersebut juga menjadi latar belakang dari perencanaan serangkaian pengadaan program baik kelompok yang menjadi program unggulan. Secara keseluruhan, berbagai program PKM dapat dilaksanakan dan berjalan sesuai dengan sasaran yang telah direncanakan. Baik program kegiatan kelompok dapat dijalankan dengan lancar.Keberhasilan berbagai program tersebut terbukti dengan antusisnya para responden atau peserta sebagai sasaran kegiatan dalam mengikuti pelaksanaan program kegiatan yang berlangsung.

\section{REFERENSI}

[1] KNKG. 2006. Pedoman Umum Good Corporate Governance Indonesia. Komite Nasional Kebijakan Governance

[2] Pemerintah Daerah Undang-Undang Nomor 32 Tahun 2004 tentang Pemerintahan Desa

[3] Peraturan Menteri Desa, Pembangunan Daerah Tertinggal dan Transmigrasi No. 4 Tahun 2015 tentang Pendirian, Pengurusan dan Pengelolaan, dan Pembubaran Badan Usaha Milik Desa.

[4] Peraturan Pemerintah No 72 Tahun 2005 tentang Desa

[5] Pusat Kajian Dinamika Sistem Pembangunan. 2007. Buku Panduan Pendirian dan Pengelolaan Badan Usaha Milik Desa. Departemen Pendidikan Nasional. Fakultas Ekonomi. Universitas Brawijaya.

[6] Putra, A.S., 2015, Badan Usaha Milik Desa: Spirit Usaha Kolektif Desa. Jakarta: Kementerian Desa, Pembangunan Daerah Tertinggal, dan Transmigrasi Republik Indonesia.

[7] Undang-Undang Nomor 6 Tahun 2014 Tentang Desa, Lembaran Negara Republik Indonesia Tahun 2014 Nomor 7, Tambahan Lembaran Negara Nomor 5495.

[8] Irwanto. 2006. Keanekaragaman Fauna pada Habitat Mangrove. Yogyakarta. 